had a higher switch rate. Despite these results, there are no differences in the EULAR response between the two groups and ANA seroconversion did not predict this response over time. Therefore, ANA induced by anti-TNF- $\alpha$ agents should be monitored in patients with rheumatoid arthritis and its impact on treatment must be considered. Further research is needed to explore these results through large-scale prospective studies.

Disclosure of Interests: None declared

DOI: 10.1136/annrheumdis-2021-eular.3265

\section{POS0489 DOES TIME TO REMISSION DIFFER DEPENDING ON ROUTE OF ADMINISTRATION OF METHOTREXATE IN AN EARLY ARTHRITIS TREAT TO TARGET (T2T) COHORT?}

1. Ali ${ }^{1} .{ }^{1}$ Our Lady's Hospital Manorhamilton, Rheumatology, Manorhamilton, Ireland

Background: Rheumatoid arthritis (RA) is a multisystem inflammatory disorder that affects the joints and other body tissues. Approximately $1 \%$ of the worldwide population is living with RA 1. Methotrexate is the first line DMARD used for treatment of RA 2

Objectives: The aim of this study was to analyse MTX use in achieving remission in early arthritis patients and to compare the route of administration to see whether it affects the time interval to remission.

Methods: An observational, prospective study was performed on patients' data available from our Early Arthritis Cohort. Newly diagnosed patients with RA meeting the American College of Rheumatology (ACR) criteria were enrolled in T2T programme led by Advanced Nurse Practitioner (ANP) with consultant supervision. To assess their response to treatment, we used the Clinical Disease Activity Index (CDAI) SPSS was used to analyse the data.

Results: A total of 353 have completed the programme and of these, 341 were commenced on MTX. 208 patients $(61 \%)$ were female. The MTX starting dose was $15 \mathrm{mg}$ for $88.4 \%$ (305/341) of patients. The median time to first increment in MTX dose was 7 weeks and the figure 1 was identical for the second increment. Of the 238 patients who started oral MTX, $18.48 \%$ (44) discontinued. $21.4 \%$ (22) of the 103 who started on SC-MTX discontinued (The $p$-value for discontinuation was 0.538 ). P-value for likelihood of achieving remission based on oral versus SC MTX was 0.248 and the $p$-value for time to achieve remission was 0.671 for oral versus SC MTX groups, see figure 1 attached.

Conclusion: Patients in this cohort are being started promptly on an appropriate dose of MTX and are escalated in a timely manner in-line with guidelines. Analysis showed no statistically significant difference in terms of time to remission, likelihood of achieving remission or discontinuation of MTX between oral and SC-MTX groups.

\section{REFERENCES:}

[1] Carmona L, Villaverde V, Hernández-García C, Ballina J, Gabriel R, Laffon $A$, et al. The prevalence of rheumatoid arthritis in the general population of Spain. Rheumatology. 2002;41(1):88-95.

[2] Rachapalli SM, Williams R, Walsh DA, Young A, Kiely PDW, Choy EH, et al. First-line DMARD choice in early rheumatoid arthritis-do prognostic factors play a role? Rheumatology. 2010;49(7):1267-71.

Disclosure of Interests: None declared

DOI: 10.1136/annrheumdis-2021-eular.3293

\section{POS0490 SERUM MATRIX METALOPROTINASE 3 AS A MARKER TO DISCRIMINATE SUBCLINICAL DISEASE ACTIVITY FROM ULTRASOUND DEFINED REMISSION IN PATIENTS WITH RHEUMATOID ARTHRITIS}

F. Hamdy ${ }^{1}$, A. F. Enein ${ }^{2}$, N. Morad ${ }^{1}$, S. Tharwat ${ }^{2}$, A. M. Abd el-Khalek ${ }^{3}$, E. E. Eltoraby ${ }^{4}{ }^{1}$ Mansoura University, Rheumatology and Immunology Unit, Mansoura, Egypt; ${ }^{1}$ Mansoura University, Rheumatology and Immunology Unit, Mansoura, Egypt: ${ }^{3}$ Mansoura University, Dignostic Radiology, Mansoura, Egypt; ${ }^{1}$ Mansoura University, Rheumatology and Immunology Unit, Mansoura, Egypt

Background: Rheumatoid arthritis (RA) is a systemic disease which results in chronic inflammation that primarily involves synovial joints resulting in progressive joint destruction [1]. Detection of subclinical disease activity is important as radiographic progression was observed during remission course in some cases [2]. Ultrasound can detect subclinical activity and synovial inflammation, which predict relapse and radiographic progression [3]
Matrix Metaloprotinase 3 (MMP-3) is an enzyme, which is involved in joint destruction in RA patients. MMP-3 was found to correlate with disease activity, joint erosions, radiographic progression, drug responsiveness and disease outcome in patients with active RA [4]. However no data about its role in detection of subclinical activity in patients with clinical remission.

Objectives: To assess the role of MMP-3 as a marker to discriminate subclinical activity from ultrasound remission in rheumatoid arthritis patients with remission.

Methods: This study was conducted on 45 RA patients fulfilling remission or low disease activity criteria according to DAS 28 AND 45 healthy controls. Ultrasound evaluation was done for all patients using modified German US7 score. According to US7 score patients were classified into two groups: group with sonographic remission in which GS is $0 \pm 1$ and the other group with subclinical disease activity with higher GS. Both groups underwent clinical and laboratory evaluation including MMP-3.

Results: Sonographic remission was achieved in $44 \%$ of patients (20 patients) There was no statistically significant difference as regard age, gender, smoking, disease duration, morning stiffness duration, CDAl, treatment and laboratory data apart from hemoglobin level between patients with subclinical disease activity and patients with remission. However, there is statistically significant difference between the two groups as regard joint deformity, extra articular manifestations, DAS 28, SDAl and hemoglobin level.

There was statistically significant difference in serum MMP-3 between RA patients and healthy control group. Serum MMP-3 was higher in RA patients with subclinical activity than patients with sonographic remission but the difference was not statistically significant (figure 1). Serum MMP-3 was positively correlated with ESR and synovitis score.

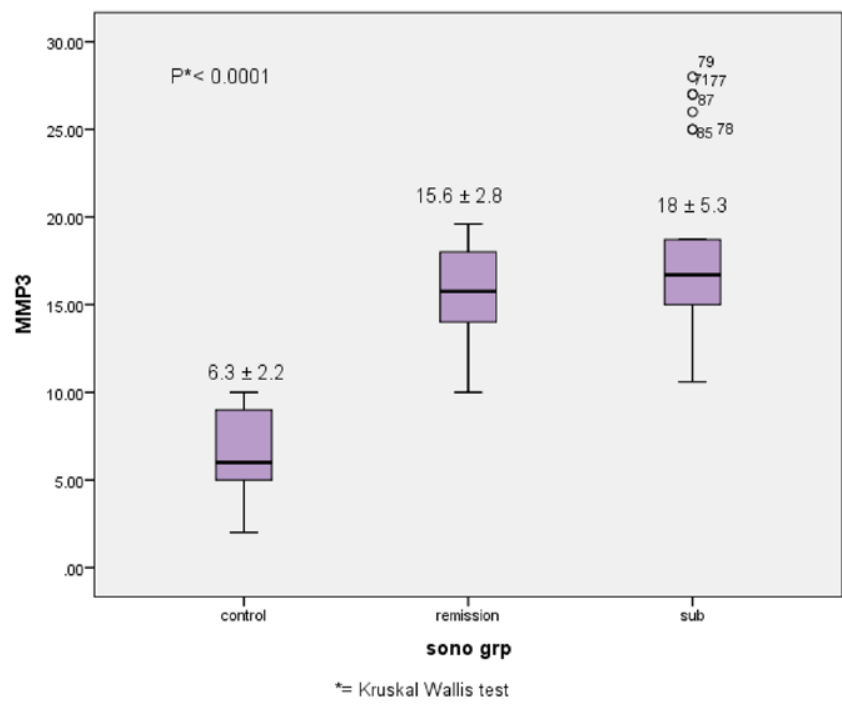

Figure 1.

Conclusion: Serum MMP-3 has correlation with US synovitis score. However serum MMP-3 was not able to differentiate patients with sonographic remission from patients with subclinical disease activity. Ultrasound is still the gold standard for detection of subclinical disease activity.

\section{REFERENCES:}

[1] Ergin, S. (2000). "Romatoid Artrit ve Sjögren Sendromu." Fiziksel Tıp ve Rehabilitasyon, Günes Kitapevi: 1549-1576.

[2] Ogishima, H., H. Tsuboi, N. Umeda, M. Horikoshi, Y. Kondo, M. Sugihara, T. Suzuki, I. Matsumoto and T. Sumida (2014). "Analysis of subclinical synovitis detected by ultrasonography and low-field magnetic resonance imaging in patients with rheumatoid arthritis." Modern rheu matology 24(1): 60-68.

[3] Filippucci, E., E. Cipolletta, R. M. Mirza, M. Carotti, A. Giovagnoni, F. Salaffi, M. Tardella, A. Di Matteo and M. Di Carlo (2019). "Ultrasound imaging in rheumatoid arthritis." La radiologia medica 124(11): 1087-1100.

[4] Lerner, A., S. Neidhöfer, S. Reuter and T. Matthias (2018). "MMP3 is a reliable marker for disease activity, radiological monitoring, disease outcome predictability, and therapeutic response in rheumatoid arthritis." Best Practice \& Research Clinical Rheumatology 32(4): 550-562.

Disclosure of Interests: None declared

DOI: 10.1136/annrheumdis-2021-eular.3314 